\title{
Antimicrobial activity of a bacteriocin produced by Lactobacillus plantarum 29V and strain's viability in Palm kernel oil
}

\author{
Zambou Ngoufack François*, Kaktcham Pierre Marie, Tiogo Azemfack Huguette Noëlle, \\ Guetiya Wadoum Raoul Emeric \\ Laboratory of Biochemistry, Food Science and Nutrition (LABPMAN) - Department of Biochemistry - Faculty of Science - University of \\ Dschang, Cameroon
}

Email address:

fzambou@yahoo.fr (Z. N. François)

To cite this article:

Zambou Ngoufack François, Kaktcham Pierre Marie, Tiogo Azemfack Huguette Noëlle, Guetiya Wadoum Raoul Emeric. Antimicrobial Activity of a Bacteriocin Produced by Lactobacillus Plantarum 29V and Strain'S Viability in Palm Kernel Oil, International Journal of Nutrition and Food Sciences. Vol. 2, No. 3, 2013, pp. 102-108. doi: 10.11648/j.ijnfs.20130203.12

\begin{abstract}
The present investigation reports the characterization of the bacteriocin produced by the probiotic strain Lactobacillus plantarum $29 \mathrm{~V}$ isolated from raw cow milk in the Western's highlands of Cameroon, as well as the viability of this strain in the palm kernel oil. The antimicrobial compound synthesized by Lactobacillus plantarum $29 \mathrm{~V}$ was sensitive to some proteolytic enzymes. It showed remarkable stability at high temperatures and in the presence of organic solvents, detergents and surfactants. It was also active in $\mathrm{pH} 2.0-10$ and $\mathrm{NaCl}$ range of 1-7\%. The neutralized cell-free supernatant of this bacterium inhibited the growth of several Lactobacillus spp., pathogenic and food spoilage microorganisms. The results of this study showed that palm kernel oil maintains the viable cell numbers of the probiotic strain Lactobacillus plantarum 29V, without any changes of peroxide and acid indexes of palm kernel oil.
\end{abstract}

Keywords: Bacteriocin, Probiotic, Lactobacillus Plantarum, Palm Kernel Oil

\section{Introduction}

The preservation of foods by natural and microbiological methods may be a satisfactory approach to solve economic losses due to microbial spoilage of raw materials and food products, as well as to reduce the incidence of food borne illnesses [1]. The increasing demand for safe foods, with low level of chemical additives, has increased the interest in replacing these compounds by natural products, which are not harmful to the host or the environment. Thus, biopreservation of food has emerged as an attractive and safe approach. The preserving effects of lactobacilli are due to the production of antimicrobial substances such as organic acids, hydrogen peroxide, and bacteriocins or related substances [2]. Although many bacteria can produce bacteriocins, those produced by lactobacilli are of particular interest to the food industry, since these bacteria have GRAS (Generally Regarded as Safe) status. Several bacteriocins from gram positive bacteria display bactericidal activity with fairly broad inhibitory spectra and may be useful as antibacterial agents for various practical applications [3]. . The increasing in- terest in bacteriocins has stimulated the isolation of lactobacilli producers and the characterization of many novel peptides [4]. It is well documented that dairy products serve as best matrix for probiotic bacteria. However, a trend of non-dairy probiotics is growing due to some issues in dairy probiotics. The dairy matrix may contain potential allergens, such as casein and cold storage during the shelf life is required. Therefore, the demand for new non-dairy matrices and the trend of vegetarianism are increasing [5]. Also producing probiotic products with foods and beverages which are part of the day-to-day life is encouraged. This leads to increased demand for non-dairy probiotic foods. In the development of novel probiotic products, the fermentability of the matrix should be considered since it can lead to an increase of the viable cell concentration. The expectation is to have a healthy product which can't induce lactose intolerance and allergy due to milk protein $[6,7]$. Also, we are hoping to characterize a new food matrix, which can carry probiotic culture at effective levels, in other to be used in developing countries since the storage conditions of already characterized food matrixes are sometimes inadequate.

Therefore, it would be interesting to find other local food 
matrix for probiotics. Palm kernel oil (PKO) has large distribution in Southern Asia, Sub-Saharan Africa and South America countries and may be important as new matrix for functional food items. PKO and its hydrogenated and fractionated products are widely used either alone or in blends with other oils for the manufacture of food products. The non-food uses of PKO are very substantial and becoming of increasing importance because, palm kernel oil and it's by products have many applications in pharmaceutical and cosmetic industries [8].

The present study reports the characterization of the bacteriocin produced by a probiotic strain Lactobacillus plantarum $29 \mathrm{~V}$ isolated from raw cow milk from the Borroro's cattle breeders in the western highlands of Cameroon as well as the assessment of the viability of this functional strain in the palm kernel oil.

\section{Materials and Methods}

\subsection{Microorganisms}

The strain Lactobacillus plantarum $29 \mathrm{~V}$ used in this study was isolated from raw cow's milk during the period October - December 2009. This strain was identified in our previous study on the basis of its morphological, carbohydrate fermentation profile by API 50CH kit and RAPD-PCR [9]. Pathogenic indicator strains such as Staphylococcus aureus ATCC 25923, Staphylococcus aureus (MDR, clinical isolate), Enterococcus faecalis ATCC 10541, Escherichia coli (MDR, clinical isolate), Salmonella enterica ssp.enterica serovare Typhi ATCC 6539, Pseudomonas aeruginosa ATCC 27853, Proteus mirabilis (clinical isolate) and Klebsiella pneumoniae (clinical isolate) were grown in tryptone broth at $37^{\circ} \mathrm{C}$. All clinical isolates were obtained from the Centre Pasteur of Yaoundé, Cameroon.

\subsection{Antimicrobial Activity Detection and Assay}

The production of antimicrobial substance was detected using the triple-agar layer method [10]. An overnight culture of the L. plantarum strain was spotted onto the surface of an MRS (Biolife, Italy) plate. Spotted plates were overlaid with a second layer of MRS Agar. The plates were incubated at $37^{\circ} \mathrm{C}$ (Incubator, Techmel TT9052, USA) for $48 \mathrm{~h}$ and then overlaid with active growing sensitive cells of L. plantarum $5 \mathrm{~S}\left(10^{8} \mathrm{CFU} / \mathrm{ml}\right)$, imbedded in a thin layer $(7 \mathrm{ml})$ of soft MRS (MRS with 7.5\% (w/v) agar). After anaerobic incubation during $24 \mathrm{~h}$ at $30^{\circ} \mathrm{C}$, the bacterial lawn was examined for zones of inhibition surrounding producer colonies. Inhibition was recorded as positive if the width of the clear zone around the colonies of the producer was $2 \mathrm{~mm}$ or larger [10].

\subsection{Screening for Bacteriocin Production}

For Bacteriocin bioassay, the producer strain (L. plantarum) was grown anaerobically in MRS broth at $37^{\circ} \mathrm{C}$ for $6 \mathrm{~h}$. Bacterial cells were removed by centrifugation (4000 g, 30 $\min , 4^{\circ} \mathrm{C}$ ) to obtain cell-free supernatant. The supernatant was neutralized using $6 \mathrm{M} \mathrm{NaOH}$ and heated at $80^{\circ} \mathrm{C}$ for 10 min. Soft MRS agar seeded with overnight cultures of the indicator strain of L. plantarum $5 \mathrm{~S}\left(10^{8} \mathrm{CFU} / \mathrm{ml}\right)$ was dispensed onto pre-poured MRS agar plates and $6 \mathrm{~mm}$ wells were punched after solidification. The wells were sealed at the bottom with sterile non-seeded agar. Fifty microliter aliquots of sterile neutralized supernatant were placed into the agar wells in duplicates for each test. The plates were then incubated for $48 \mathrm{~h}$ at $37^{\circ} \mathrm{C}$. Sterile un-inoculated MRS broth was used as control.

\subsection{Determination of Bacteriocin Titer}

The bacteriocin activity was determined by the critical dilution method, as described by Biswas et al. [11] . Neutralized cell-free supernatant of the L. plantarum strain grown in MRS broth at $37^{\circ} \mathrm{C}$ for $24 \mathrm{~h}$ was serially diluted (1:2 to $1: 128)$ using sterile distilled water. A $10 \mu$ portion, in duplicate, from each dilution, was spotted directly onto MRS agar plates which were previously overlaid with soft MRS agar medium seeded with L. plantarum $5 \mathrm{~S}$ cells $\left(10^{8}\right.$ $\mathrm{CFU} / \mathrm{ml}$ approximately). The plates were incubated at $37^{\circ} \mathrm{C}$ for $24 \mathrm{~h}$ and examined for zones of inhibition. The highest dilution that produced a clear zone of inhibition was multiplied by $100(1 \mathrm{ml} / 10 \mu \mathrm{l})$ to obtain the arbitrary units per milliliter $(\mathrm{AU} / \mathrm{ml})$.

\subsection{Effects of Enzymes on Bacteriocin Activity Microor- ganisms}

Sensitivity to proteolytic enzymes was checked when bacteriocin sample was treated with trypsin (Fluka Biochemika, Buchs, Switzerland) in $0.05 \mathrm{M}$ Tris-HCl buffer, $\mathrm{pH}$ 8.0; Proteinase K (Merck, Darmstadt, Germany) in $0.05 \mathrm{M}$ phosphate buffer, pH 7.0;

$\alpha$-Amylase (Sigma-Aldrich, Steinheim, Germany) in 0.05 M phosphate buffer, pH 7.0; lipase (Sigma-Aldrich, Steinheim, Germany) in $0.05 \mathrm{M}$ phosphate buffer, $\mathrm{pH} 7.0$; and lysozyme (Fluka Biochemika, Buchs, Switzerland) in 0.05 $\mathrm{M}$ phosphate buffer, $\mathrm{pH}$ 7.0. Fifty microliters of the partially purified bacteriocin was lyophilized and resuspended in enzymes solutions at $1 \mathrm{mg} / \mathrm{ml}$ final concentration. Incubation was held at $37^{\circ} \mathrm{C}$ for $1 \mathrm{~h}$. After incubation, the enzymes were denatured by heating the samples at $80^{\circ} \mathrm{C}$ for $10 \mathrm{~min}$ and the residual bacteriocin activity was determined as described above.

\subsection{Effects of Ph, Temperature, Nacl and Chemicals on Bacteriocins Activity}

The effect of $\mathrm{pH}$ on the bacteriocin was determined by resuspending the lyophilized partially purified bacteriocin into buffer solutions (50 mM acetate buffer, $\mathrm{pH} 2.0$ and 3.0 ; $50 \mathrm{mM}$ potassium phosphate buffer, $\mathrm{pH} 4.0 ; 5.0 ; 6.0$ and 7.0; $50 \mathrm{mM}$ Tris - HCl buffer, $\mathrm{pH} 8.0 ; 9.0$ and 10.0. After $2 \mathrm{~h}$ of incubation at room temperature, the samples were readjusted to $\mathrm{pH} 6.5$ with sterile $6 \mathrm{M} \mathrm{HCl}$ or $6 \mathrm{M} \mathrm{NaOH}$ and the activity determined as described previously [12]. The effect of SDS, tween 20 , tween 80 , urea, and triton X-100 was tested by suspending lyophilized partially purified bacteriocin in each 
of $1 \%(\mathrm{v} / \mathrm{v}$ or $\mathrm{w} / \mathrm{v})$ chemical solutions. $\mathrm{NaCl}$ was used at the final concentrations of $7 \%(\mathrm{w} / \mathrm{v})$. After $5 \mathrm{~h}$ of incubation at room temperature the activity was determined. The effect of temperature on the bacteriocin was tested by heating the partially purified bacteriocin suspension at $80^{\circ} \mathrm{C}$ for $10 \mathrm{~min}$, $100^{\circ} \mathrm{C}$ for $30,60,90$ and $120 \mathrm{~min}$, and $121^{\circ} \mathrm{C}$ for 15,20 and 30 min [10]. After each treatment, residual bacteriocin activity was determined.

\subsection{Growth Rate and Bacteriocin Production}

To evaluate the growth of strain L. plantarum 29V in MRS broth at $37^{\circ} \mathrm{C}$, a turbidimetric method was used [13]. Bacterial growth was measured as the absorbance of cell suspensions at $600 \mathrm{~nm}$ using UV/VIS spectrophotometer (Shimadzu UV-1208) at 0, 2, 4, 6, 8, 10 and 12h. For determining bacteriocin production in relation with incubation time, the strain was inoculated into MRS broth and incubated at $37^{\circ} \mathrm{C}$ for $12 \mathrm{~h}$. The samples were aseptically withdrawn, in duplicates, from the culture media at $2 \mathrm{~h}$ intervals throughout the incubation period. The bacteriocin activities of each sample were recorded and the results were compared.

\subsection{Assessment of the Viability of the Bactero- cin-Producing L. Plantarum 29V Strain in Palm Kernel Oil (PKO)}

The palm kernel oil samples (PKO) were purchased in the local market. Before use, it was heated at $63{ }^{\circ} \mathrm{C}$ for $30 \mathrm{~min}$ and introduced in $100 \mathrm{ml}$ sterile vials. In a separate experiment, L. plantarum culture were propagated twice in MRS broth and incubated at $37{ }^{\circ} \mathrm{C}$ for $16 \mathrm{~h}$. Seventy milliliter of broth media were inoculated with $10 \%$ overnight, activated culture of strain L. plantarum 29V. The growth of the culture in broth media was monitored by UV/VIS spectrophotometer (Shimadzu UV-1208) for $6 \mathrm{~h}$. At the early stationary growth phase, bacterial cells were harvested from the media by centrifugation of the culture $\left(4000 \mathrm{~g}, 30 \mathrm{~min}, 4^{\circ} \mathrm{C}\right)$. The pellet was then washed twice with $0.01 \mathrm{M}$ potassium phosphate buffer $\mathrm{pH}$ 7.0. The resultant pellet was suspended in $100 \mathrm{ml}$ sterile potassium phosphate buffer $0.01 \mathrm{M}$ and stored at $-20^{\circ} \mathrm{C}$ until used. The viable cell count of this suspension was determined by enumeration on MRS plate agar. One hundred microliters of this concentrate $\left(10^{8}\right.$ $\mathrm{CFU} / \mathrm{ml}$ ) was thoroughly homogenized and introduced into $100 \mathrm{ml}$ of PKO. Non- inoculated PKO samples were used as control. Inoculated and non-inoculated PKO samples were stored at $25{ }^{\circ} \mathrm{C}$ (room temperature) and $4{ }^{\circ} \mathrm{C}$ respectively for 30 days.

From the inoculated PKO samples, an aliquot of $10 \mathrm{ml}$ was taken at 10-days interval for viable cell counts of L. plantarum. Ten-fold serial dilutions were done in $0.1 \%$ DMSO (in physiological saline solution) while homogenizing by vortexing, followed by viable cell count on MRS agar using the pour plate technique. Plates were incubated anaerobically at $37^{\circ} \mathrm{C}$ for $48 \mathrm{~h}$.

The acid and peroxide indexes of PKO samples were de- termined according to standard NFT60-204 of the French Association for Standardization [14]. These analyses were performed at 10-days interval.

\subsection{Statistical Analyses}

Concerning the physico-chemical characteristics of PKO samples, data representing means and standard deviation of three independent experiments were subjected to Analysis of Variance (ANOVA) and multiple comparisons were done by Student-Newman-Keuls test, using the software GraphPad InStat (GraphPad Software Inc, V3).

\section{Results and Discussion}

\subsection{Screening of Bacteriocin Activity}

The zones of inhibition observed in initial screening using triple-agar layer test and Agar Well Diffusion Assay showed the presence of antibacterial activity against indicator strain L. plantarum 5S. The Neutralized cell-free supernatant of L. plantarum $29 \mathrm{~V}$ culture demonstrated inhibitory activity of $1600 \mathrm{AU} / \mathrm{ml}$, which decreased to $800 \mathrm{AU} / \mathrm{ml}$ after partial purification using $60 \%$ ammonium sulfate precipitation. This is in agreement with the findings of Todorov et al. [15] reporting the loss of plantaricin ST31 activity from $6.4 \times 10^{5}$ to $2.5 \times 10^{5} \mathrm{AU} / \mathrm{ml}$ after $60 \%$ ammonium sulfate precipitation. Since inhibition was observed when the pathogens were grown in the presence of near-neutral supernatant $(\mathrm{pH}$ 6.5), inhibition effects could not be attributed to organic acids production, but probably to hydrogen peroxide or bacteriocin-like substances production. However, the antimicrobial activity of the inhibitory substance appeared unrelated to hydrogen peroxide as their activity was not lost after triple-agar layer test (i.e under anaerobic conditions).

\subsection{Effects of Enzymes, Ph, Temperature, Nacl and Chemicals on Bacteriocins Activity}

The sensitivity of the inhibitory substance to trypsin, proteinase $\mathrm{K}, \alpha$-amylase, lysozyme and lipase was determined in controlled and reproducible conditions as shown in Table 1 . The inhibitory substance was fully inactivated by proteolytic enzymes. $\alpha$-amylase, lysozyme and lipase had no effect on the activity, thus confirming its proteinaceous nature.

extensive research [16]. According to Fricourt et al. [17], lactic acid bacteria synthesize bactericidal agents that vary in their spectra of activity. Many of these agents are bacteriocins with a proteinaceous active moiety, while others are non-protein agents [18]. During our investigations, complete loss of the antagonistic activity after exposure to proteases, owing to the proteinaceous nature of the bacteriocins. Similar results were reported by Tiwari and Srivastava [12] on plantaricin LR/14.

Results of the effect of temperature revealed that bacteriocin from L. plantarum $29 \mathrm{~V}$ (P29V) showed strong heat stability, as $75 \%$ and $50 \%$ activity could still be recorded upon treatment at $100^{\circ} \mathrm{C}$ for $120 \mathrm{~min}$ and $121^{\circ} \mathrm{C}$ for $30 \mathrm{~min}$ 
respectively (Table 1). Bacteriocin from L. plantarum F1 is reported to be stable at $121{ }^{\circ} \mathrm{C}$ up to $10 \mathrm{~min}$ [19]. Plantaricin TF711 retained $70 \%$ activity after boiling and no activity upon autoclaving [20]. The retention of activity by P29V after heating at $121{ }^{\circ} \mathrm{C}$ for $30 \mathrm{~min}$, place it within heat stable group of bacteriocins. This quality of the bacteriocin makes it superior in processed food stuffs where high heat is applied.

Table 1. Effect of enzymes, temperature and $\mathrm{pH}$ on the activity of the bacteriocin produced by strain L. plantarum $29 \mathrm{~V}$.

\begin{tabular}{|c|c|c|c|}
\hline \multicolumn{4}{|c|}{ Bacteriocin produced by strain L. plantarum 29V } \\
\hline Treatment & $\begin{array}{l}\text { Activity } \\
(\mathrm{mm})\end{array}$ & $\begin{array}{l}\text { Activity } \\
\text { (AU/ml) }\end{array}$ & $\begin{array}{l}\text { Residual activity } \\
(\%)\end{array}$ \\
\hline Control & 8 & 800 & 100 \\
\hline \multicolumn{4}{|c|}{ Effect of enzymes } \\
\hline Trypsine & 0 & 0 & 0 \\
\hline Proteinase $\mathrm{K}$ & 0 & 0 & 0 \\
\hline Amylase & 7 & 800 & 87.5 \\
\hline Lipase & 8 & 800 & 100 \\
\hline Lysozyme & 7 & 800 & 87.5 \\
\hline \multicolumn{4}{|c|}{ Effect of temperature } \\
\hline $80^{\circ} \mathrm{C}, 10 \mathrm{~min}$ & 8 & 800 & 100 \\
\hline $100^{\circ} \mathrm{C}, 30 \mathrm{~min}$ & 8 & 800 & 100 \\
\hline $100^{\circ} \mathrm{C}, 60 \mathrm{~min}$ & 6 & 400 & 75 \\
\hline $100^{\circ} \mathrm{C}, 90 \mathrm{~min}$ & 6 & 400 & 75 \\
\hline $100^{\circ} \mathrm{C}, 120 \mathrm{~min}$ & 4 & 200 & 75 \\
\hline $121^{\circ} \mathrm{C}, 15 \mathrm{~min}$ & 6 & 400 & 75 \\
\hline $121^{\circ} \mathrm{C}, 20 \mathrm{~min}$ & 6 & 400 & 75 \\
\hline $121^{\circ} \mathrm{C}, 30 \mathrm{~min}$ & 4 & 200 & 50 \\
\hline \multicolumn{4}{|l|}{ Effect of $\mathrm{pH}$} \\
\hline $\mathrm{pH} 2$ & 8 & 800 & 100 \\
\hline pH 3 & 8 & 800 & 100 \\
\hline $\mathrm{pH} 4$ & 8 & 800 & 100 \\
\hline $\mathrm{pH} 5$ & 8 & 800 & 100 \\
\hline pH 6 & 8 & 800 & 100 \\
\hline pH 7 & 8 & 800 & 100 \\
\hline pH 8 & 8 & 800 & 100 \\
\hline pH 9 & 8 & 800 & 100 \\
\hline $\mathrm{pH} 10$ & 8 & 800 & 100 \\
\hline
\end{tabular}

Residual activity was expressed as the percentage of diameter of inhibition zone of the test by the diameter of inhibition zone of the control

The bacteriocin P29V produced by L. plantarum 29V was not sensitive to $\mathrm{pH}$. It showed stable activity between $\mathrm{pH} 2.0$ and 10.0. Similar results were reported by Hernández et al.
[20] on bacteriocins produced by L. plantarum TF711 on the one hand. On the other hand, the bacteriocins produced by L. plantarum F1 was active between $\mathrm{pH} 2.0$ and 12.0 but with only $50 \%$ and $6.2 \%$ activity at $\mathrm{pH} 8.0$ and 12.0 , respectively [19] . P29V showed good stability against the tested solvents and surfactants (Table 2). Additionally, high stability of $\mathrm{P} 29 \mathrm{~V}$ was observed at different $\mathrm{NaCl}$ concentrations, similarly to the findings of Tiwari and Srivastava [12] on plantaricin LR/14.

Table 2. Effect of chemicals on the activity of the bacteriocin produced by strain L. plantarum $29 \mathrm{~V}$.

\begin{tabular}{|c|c|c|c|}
\hline \multicolumn{4}{|c|}{ Bacteriocin produced by strain L. plantarum $29 \mathrm{~V}$} \\
\hline Treatment & $\begin{array}{l}\text { Activity } \\
(\mathrm{mm})\end{array}$ & $\begin{array}{l}\text { Activity } \\
(\mathbf{A U} / \mathrm{ml})\end{array}$ & $\begin{array}{l}\text { Residual activity } \\
(\%)\end{array}$ \\
\hline Control & 8 & 800 & 100 \\
\hline \multicolumn{4}{|c|}{ Effect of organic solvent } \\
\hline Acetone & 8 & 800 & 100 \\
\hline Acetonitrile & 8 & 800 & 100 \\
\hline Chloroforme & 8 & 800 & 100 \\
\hline Ethanol & 8 & 800 & 100 \\
\hline isopropanol & 8 & 800 & 100 \\
\hline Methanol & 8 & 800 & 100 \\
\hline \multicolumn{4}{|c|}{$\begin{array}{l}\text { Effect of detergent and } \\
\text { surfactant }\end{array}$} \\
\hline SDS & 6 & 400 & 75 \\
\hline Triton X-100 & 8 & 800 & 100 \\
\hline Tween 20 & 8 & 800 & 100 \\
\hline Tween 80 & 8 & 800 & 100 \\
\hline Urea & 8 & 800 & 100 \\
\hline \multicolumn{4}{|l|}{ Effect of $\mathrm{NaCl}$} \\
\hline $1 \%$ & 8 & 800 & 100 \\
\hline
\end{tabular}

Residual activity was expressed as the percentage of diameter of inhibition zone of the test by the diameter of inhibition zone of the control.

\subsection{Growth Rate and Bacteriocin Production}

The strain L. plantarum 29V showed a typical sigmoidal growth response (Figure 1), consisting of a short lag phase of $\sim 2 \mathrm{~h}$ and reaching the stationary phase by $8-10 \mathrm{~h}$. Bacteriocin production followed a growth-associated pattern. Production of bacteriocin occurred throughout logarithmic growth, with the highest activity recorded at the end of logarithmic and during stationary growth $(8-10 \mathrm{~h})$. Thereafter, antimicrobial activity decreased. These characteristics are common to most known bacteriocin producing lactic acid bacteria [21]. Staphylococcus warneri FM20 and L. plantarum TF711 showed similar trend of growth and bacteriocin production [20]. Such a decreased in bacteriocins production could be assigned to the sensitivity of bacteriocin to proteolytic enzymes secreted by the producer bacterium, given that the production of other bacteriocins such as plantaricin TF711 by L. plantarum LR/14 was reported to be maintained after late log phase [12]. 


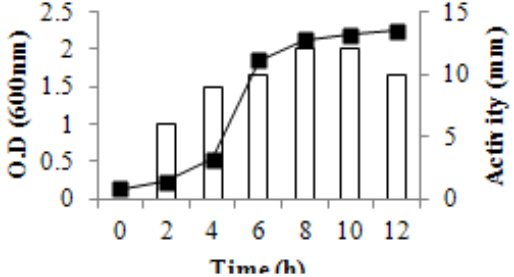

Figure 1. Cell growth and bacteriocin (P29V) production at different time of incubation in MRS Broth..

\subsection{Bacteriocin Spectrum of Inhibitory Activity}

As shown in Table 3, growth inhibition was tested against pathogenic gram-positive and gram-negative bacteria. The crude preparation of cell-free neutralized supernatant of $\mathrm{L}$. plantarum $29 \mathrm{~V}$ culture displayed a broad spectrum inhibition. Interestingly, among the strains checked, some are strictly food-borne pathogens. Bacteriocin P29V exhibited a wider spectrum of inhibition against gram positive and gram negative pathogens, as also reported by Todorov et al. [15]. The potential of this bacteriocin to inhibit the food-borne pathogens such as Staphylococcus aureus ATCC 25923, Staphylococcus aureus (MDR, clinical isolate), Escherichia coli (MDR, clinical isolate), Salmonella enterica ssp. enterica serovare Typhi ATCC 6539, makes it of crucial interest especially in processed foods where there is risk of food-borne pathogens. High thermostability and broad antimicrobial spectrum is further supplemented by its stability in the presence of $\mathrm{NaCl}$, organic solvents, surfactants, and detergents. This indicates that the antimicrobial compound from strain $29 \mathrm{~V}$ could preserve its structure and bactericidal functions even under extreme conditions, which is an important property in view of its potential application.

Table 3. Spectrum of inhibitory activity of the bacteriocin produced by strain L. plantarum $29 \mathrm{~V}$.

\begin{tabular}{|c|c|c|c|}
\hline $\begin{array}{l}\text { Indicator strains } \\
\text { Lactic acid bacteria } \\
\end{array}$ & Source & $\begin{array}{l}\text { Growth } \\
\text { conditions }\end{array}$ & Bacteriocin Activity (mm) \\
\hline L. plantarum 5S & Our collection & $\mathrm{MRS}^{\mathrm{c}}, 30^{\circ} \mathrm{C}$ & $13.0 \pm 0.0$ \\
\hline L. plantarum $2 \mathrm{~S}$ & Our collection & $\mathrm{MRS}, 30^{\circ} \mathrm{C}$ & $0.0 \pm 0.0$ \\
\hline L. plantarum 3S & Our collection & $\mathrm{MRS}, 30^{\circ} \mathrm{C}$ & $0.0 \pm 0.0$ \\
\hline L. plantarum 9S & Our collection & MRS, $30^{\circ} \mathrm{C}$ & $0.0 \pm 0.0$ \\
\hline L. rhamnosus $1 \mathrm{~K}$ & Our collection & $\mathrm{MRS}, 30^{\circ} \mathrm{C}$ & $0.0 \pm 0.0$ \\
\hline L. plantarum $18 \mathrm{~V}$ & Our collection & $\mathrm{MRS}, 30^{\circ} \mathrm{C}$ & $11.0 \pm 0.0$ \\
\hline Enterococcus faecium & DSM $^{\mathrm{a}} 13596$ & $\mathrm{BHI}^{\mathrm{d}}, 30^{\circ} \mathrm{C}$ & $0.0 \pm 0.0$ \\
\hline Enterococcus faecalis & ATCC 10541 & $\mathrm{BHI}, 30^{\circ} \mathrm{C}$ & $8.2 \pm 0.3$ \\
\hline \multicolumn{4}{|c|}{ Gram positive pathogenic bacteria } \\
\hline Listeria innocua & ATCC $^{\mathrm{b}} 33090$ & $\mathrm{~T}, \mathrm{PCA}^{\mathrm{e}}, 37^{\circ} \mathrm{C}$ & $15.3 \pm 0.5$ \\
\hline Staphylococcus. aureus & ATCC 25923 & $\mathrm{~T}, \mathrm{PCA}, 37^{\circ} \mathrm{C}$ & $12.0 \pm 0.0$ \\
\hline S. aureus (MDR) & clinical isolate & $\mathrm{T}, \mathrm{PCA}, 37^{\circ} \mathrm{C}$ & $8.0 \pm 0.4$ \\
\hline Bacillus cereus & ATCC 11778 & $\mathrm{~T}, \mathrm{PCA}, 37^{\circ} \mathrm{C}$ & $0.0 \pm 0.0$ \\
\hline Streptococcus mutans & DSM 20523 & $\mathrm{~T}, \mathrm{PCA}, 37^{\circ} \mathrm{C}$ & $14.3 \pm 1.1$ \\
\hline \multicolumn{4}{|c|}{ Gram negative pathogenic bacteria } \\
\hline Pseudomonas aeruginosa & ATCC 27853 & $\mathrm{~T}, \mathrm{PCA}, 37^{\circ} \mathrm{C}$ & $12.3 \pm 0.5$ \\
\hline Escherichia coli & ATCC 13706 & $\mathrm{~T}, \mathrm{PCA}, 37^{\circ} \mathrm{C}$ & $13.6 \pm 1.1$ \\
\hline Escherichia coli (MDR) & clinical isolate & $\mathrm{T}, \mathrm{PCA}, 37^{\circ} \mathrm{C}$ & $7.3 \pm 0.5$ \\
\hline Schigella flexneri & clinical isolate & $\mathrm{T}, \mathrm{PCA}, 37^{\circ} \mathrm{C}$ & $14.3 \pm 0.5$ \\
\hline Klebsiella pneumoniae & clinical isolate & $\mathrm{T}, \mathrm{PCA}, 37^{\circ} \mathrm{C}$ & $0.0 \pm 0.0$ \\
\hline Pseudomonas mirabilis & clinical isolate & $\mathrm{T}, \mathrm{PCA}, 37^{\circ} \mathrm{C}$ & $15.0 \pm 1.0$ \\
\hline Salmonella Typhi & ATCC 6539 & $\mathrm{~T}, \mathrm{PCA}, 37^{\circ} \mathrm{C}$ & $13.6 \pm 1.1$ \\
\hline
\end{tabular}

*: Inhibition zone Diameters are means of triplicates; Wells (6 mm in diameter) were filled with $100 \mu$ l of NCFS (Neutralized Cell-free supernatant). MDR

= Multi Drug Resistant.; ${ }^{a}$ : DSM: Deutsche Sammlung von Mikroorganismen und Zellkulturen GmbH, Braunschweig, Germany.

b: ATCC: American Type Culture Collection, Manassas, VA, USA. ${ }^{c}$ : de Man, Rogosa and Sharpe. ${ }^{d}:$ Brain Heart Infusion. ${ }^{e}:$ T, PCA: Tryptone $5 \%$, Plate Count Agar.

\subsection{Viability of the Bacteriocin-Producing L. Plantarum 29V Strain in Palm Kernel Oil (PKO)}

As shown in Table 4, the results revealed that strain $L$. plantarum $29 \mathrm{~V}$ maintains its stability in the palm kernel oil when stored at room temperature $\left(25^{\circ} \mathrm{C}\right)$ as well as at refrigeration temperature $\left(4^{\circ} \mathrm{C}\right)$ for 30 days. This could be due to the composition of palm kernel oil, mainly its high fatty 
acids content [8]. Due to the composition of palm kernel oil, probiotics can't make the food matrix more acidic with their

fermentative metabolism.

Table 4. Evolution of Acid index, Peroxide index and viable cells count of L. plantarum in Palm Kernel Oil (PKO) samples stored at different conditions.

\begin{tabular}{|c|c|c|c|c|c|}
\hline Parameters & $\begin{array}{l}\begin{array}{l}\text { Duration of } \\
\text { storage } \\
\text { (days) }\end{array} \\
\end{array}$ & $\begin{array}{l}\text { PKO + L plantarum 29V } \\
\text { stored at refrigeration tem- } \\
\text { perature }\left(4^{\circ} \mathrm{C}\right)\end{array}$ & $\begin{array}{l}\text { PKO + L. plantarum } 29 \mathrm{~V} \\
\text { stored at room temperature } \\
\left(25^{\circ} \mathrm{C}\right)\end{array}$ & $\begin{array}{l}\text { PKO stored at refrigera- } \\
\text { tion temperature }\left(4^{\circ} \mathrm{C}\right)\end{array}$ & $\begin{array}{l}\text { PKO stored at room } \\
\text { temperature }\left(25^{\circ} \mathrm{C}\right)\end{array}$ \\
\hline \multirow{4}{*}{$\begin{array}{l}\text { Acid Index } \\
(\mathrm{mgKOH} / \mathrm{g})\end{array}$} & 0 & $0.80 \pm 0.03$ & $0.80 \pm 0.03$ & $0.80 \pm 0.03$ & $0.80 \pm 0.03$ \\
\hline & 10 & $0.82 \pm 0.04$ & $0.83 \pm 0.00$ & $0.82 \pm 0.00$ & $0.82 \pm 0.11$ \\
\hline & 20 & $0.82 \pm 0.00$ & $0.89 \pm 0.00$ & $0.82 \pm 0.00$ & $0.84 \pm 0.00$ \\
\hline & 30 & $0.83 \pm 0.00$ & $0.87 \pm 0.00$ & $0.87 \pm 0.00$ & $0.87 \pm 0.00$ \\
\hline \multirow{4}{*}{$\begin{array}{l}\text { Peroxide Index } \\
\left(\mathrm{Meq}_{2} / \mathrm{Kg}\right)\end{array}$} & 0 & $10 \pm 0.69$ & $10 \pm 0.69$ & $10 \pm 0.69$ & $10 \pm 0.69$ \\
\hline & 10 & $12 \pm 0.10$ & $13 \pm 0.06$ & $11 \pm 0.04$ & $15 \pm 0.06$ \\
\hline & 20 & $27 \pm 0.16$ & $31 \pm 0.16$ & $25 \pm 0.48$ & $31 \pm 0.95$ \\
\hline & 30 & $43 \pm 0.25$ & $45 \pm 1.00$ & $37 \pm 0.95$ & $45 \pm 0.80$ \\
\hline \multirow{4}{*}{$\begin{array}{l}\text { Viable cell coun } \\
\text { L. plantarum } \\
\text { (Log CFU/ml) }\end{array}$} & 0 & $10.0 \pm 0.56$ & $10.0 \pm 0.56$ & 0 & 0 \\
\hline & $\mathrm{f}_{10}$ & $11.0 \pm 0.32$ & $10.5 \pm 0.50$ & 0 & 0 \\
\hline & 20 & $10.0 \pm 0.21$ & $8.5 \pm 0.70$ & 0 & 0 \\
\hline & 30 & $9.5 \pm 0.56$ & $9.5 \pm 0.64$ & 0 & 0 \\
\hline
\end{tabular}

Values in this table are means and standard deviation of three independent experiments.

In their previous study, Kailasapathty [22] reports that, survival of probiotics in a suitable food matrix is affected by a range of factors including $\mathrm{pH}$, post-acidification (during storage) in fermented products, hydrogen peroxide production, oxygen toxicity (oxygen permeation through packaging), storage temperatures, stability in dried or frozen form and lack of proteases. All these factors raise the stress on the microorganisms in keeping their physiological and biological functions or the functionality of cells within the matrix. The stress conditions may cause the probiotic cells "a sub-lethal injury" preventing the cell division [23] . Lactic acid bacteria have defense mechanisms such as producing stress-induced proteins to regulate stress conditions and maintain the viability in food matrices [24] . Under such conditions, cell could be non-culturable, but still alive.

In addition, peroxide and acid indexes increase in all the samples during storage (Table 4). Lower temperatures slow down the oxidation and hydrolysis of oil. Similar results were reported by Kapseu et al. [8] showing that the peroxide values as well as the free acidity increase with temperature. The increase of free acidity, combined with the increase in peroxide value could be due to the hydrolytic activity of triglycerides in the palm kernel oil which releases free fatty acids subjected to oxidation. It is important to mention that the palm kernel oil was heated at $63^{\circ} \mathrm{C}$ for $30 \mathrm{~min}$ before use.

\section{Conclusion}

The present investigation has detected a bacteriocinogenic proteinaceous compound with excellent stability and fairly broad antimicrobial spectrum. The fact that this bacteriocinogenic activity is stable under a wide range of storage conditions should allow its usage in diverse food applications to prevent the growth of pathogenic and spoilage micro-organisms. Further studies on the protein sequence and various applications on growth optimization and large-scale production are underway. Palm kernel oil maintains the viable cell numbers of L. plantarum $29 \mathrm{~V}$ after 30 days of storage.

\section{References}

[1] Galvez, R. Lucas-Lopez and H. Abriouel, "Application of bacteriocins in the control of foodborne pathogenic and spoilage bacteria". Critical Reviews in Biotechnology, 2008, 28: $125-152$.

[2] L. Cocolin, R. Foschino, G. Comi and M.G. Fortina, "Description of the bacteriocins produced by two strains of Enterococcus faecium isolated from Italian goat milk". Food Microbiology, 2007, 31: 753-758.

[3] M.M.A. Lemos, A.C. Dias and G.L.S. de Castro Ferreira, "Inhibition of vancomycin and high-level aminoglycoside-resistant enterococci strains and Listeria monocytogenes by bacteriocin-like substance produced by Enterococcus faecium E86". Current Microbiology, 2008, 57: 429-436.

[4] S.F. Deraz, E.N. Karlsson, M. Hedstrom, M.M. Andersson and B. Mattiasson, "Purification and characterisation of acidocin D20079, a bacteriocin produced by Lactobacillus acidophilus DSM 20079”. Journal of Biotechnology , 2005, 117:343-354.

[5] R.D.S.C. Ranadheera, S.K. Baines and M. C. Adams, "Importance of food in Probiotic Efficacy". Food Research International, 2010, 43: 1-7.

[6] D. Granato, G.F. Branco, F. Nazzaro, A.G. Cruz and J.A.F. Faria, "Functional Food and Nondairy Probiotic Food Development: Trends, Concepts and Products. Comprehensive" Reviews in Food Science and Food Safety, 2010, 9: 292-30.

[7] Y. Rivera-Espinoza, and Y. Gallardo-Navarro, "Non-dairy 
probiotic products. Food Microbiology, 2010, 27: 1-11.

[8] Kapseu, C. Tchiegang, J. Dellacherie and M.Dirand, Huiles noix de coco de palmiste cameroun : sources d'acide gras laurique. sostanze grasse, 1997, $74: 205-7$.

[9] D.V. Sieladie, N.F. Zambou, A. Cresci, A.F. Fonteh, P.M. Kaktcham and M.F. Tchouanguep, "Probiotic properties of lactobacilli strains isolated from raw cow milk in the western highlands of Cameroon". Innovative Romanian Food Biotechnology, 2011, 9: 12-28.

[10] S.D. Torodov, and L.M.T. Dicks, "Lactobacillus plantarum isolated from molasses produces bacteriocins active against Gram-negative bacteria”. Enzyme and Microbial Technology, 2005, 36: 318-326.

[11] S.R. Biswas, P. Ray, M.C. Johnson and B. Ray, "Influence of growth conditions on the production of a bacteriocin, pediocin ACH, by Pediococcus acidilactici H. Applied Environmental Microbiology, 1991, 57: 1265-1267.

[12] S.K. Tiwari, and S. Srivastava, "Characterization of a Bacteriocin from Lactobacillus plantarum Strain LR/14". Food Biotechnology, 2008, 22: $247-261$.

[13] T. Ignatova, I. Iliev, N. Kirilov, T. Vassileva, M. Dalgalarrondo, T. Haertle, J.M. Chobert and I. Ivanova, "Effect of oligosaccharides on the growth of Lactobacillus delbrueckii subsp. bulgaricus strains isolated from dairy products". Journal of Agricultural and Food Chemistry, 2009, 57: 9496-9502.

[14] AFNOR, "Recueil des normes Françaises des corps gras, graines oléagineuses, produits dérivés". 2e Ed. AFNOR, Paris, 1981, 438p.

[15] S.D. Todorov, C.A. Van Reenen and L.M.T. Dicks, "Optimization of bacteriocin production by Lactobacillus plantarum ST13BR, a strain isolated from barley beer". Journal of General Applied Microbiology, 2004, 50: 149-157.

[16] N. Mojgani, , G. Sabiri, M. Ashtiani, and M. Torshizi,
"Characterization of bacteriocins produced by L. brevis NM 24 and L. fermentum NM 332 isolated from green olives in Iran". The Internet Journal of Microbiology. 2009, 6 (2).

[17] B.V. Fricourt, S.F. Barefoot, R.F. Testin and S.S. Hayasaka, "Detection and activity of plantaricin $\mathrm{F}$ an antibacterial substance from Lactobacillus plantarum BF001 isolated from processed channel catfish". Journal of Food Protection, 1994, 57: 698-702.

[18] L. Saavedra, C. Minahk, A.P. Holgado and F. Sesma, "Enhancement of the enterocin CRL35 activity by a synthetic peptide derived from the NH2-terminal sequence". Antimicrobiological Agents Chemotherapies, 2004, 48: 2778-278.

[19] S.T. Ogunbanwo, A. Sanni and A. Onilude, "Characterization of bacteriocin produced by Lactobacillus plantarum F1 and Lactobacillus brevis". African Journal of Biotechnology, 2003, 2: 219-227.

[20] Hernández, E. Cardell and V. Zárate, "Antimicrobial activity of lactic acid bacteria isolated from Tenerife cheese: initial characterization of plantaricin TF711, a bacteriocin-like substance produced by Lactobacillus plantarum TF711". Journal of Applied Microbiology, 2005, 99: 77-84.

[21] M. De Kwaadsteniet, S.D. Todorov, H. Konoetze and L.M.T Dicks, "Characterization of a 3944 Da bacteriocin, produced by Enterococcus mundtii ST15, with activity against gram-positive and gram-negative bacteria". International Journal of Food Microbiology, 2005,105: 433-444.

[22] K. Kailasapathy, "Microencapsulation of Probiotic Bacteria: Technology and Potential Applications". Current Issues in Intestinal Microbiology, 2002, 3:39-48.

[23] J.D. Oliver, "The viable but nonculturable state in bacteria". The Journal of Microbiology, 2005, 43: 93-100.

[24] M.V. De Guchte, P. Serror, C. Chervaux, T. Smokvina, S. Ehrlich and E. Maguin,. "Stress responses in lactic acid bacteria". Antonie Van Leeuwenhoek, 2002, 82: 187-21. 